Jurnal Konstruksi Hukum | ISSN: XXXX | E-ISSN: XXXX Vol. 1, No. 1, September 2020 Hal. 220-226| Available online at https://www.ejournal.warmadewa.ac.id/index.php/jukonhum DOI: https://doi.org/10.22225/jkh.1.1.2138.220-226

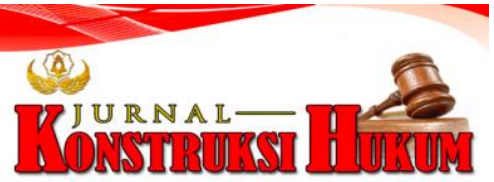

\title{
ANAK SEBAGAI KORBAN TINDAK PIDANA PERDAGANGAN ORANG MENURUT UNDANG-UNDANG NO. 35 TAHUN 2014
}

\author{
Gede Agus Sukawantara, Anak Agung Sagung Laksmi Dewi, Luh Putu Suryani \\ Fakultas Hukum Universitas Warmadewa, Denpasar-Bali, Indonesia
}

\begin{abstract}
Abstrak
Anak adalah amanah dan karunia Tuhan Yang Maha Esa yang dalam dirinya juga melekat harkat dan martabat sebagai manusia seutuhnya. Anak adalah tunas, potensi, dan generasi muda penerus cita -cita perjuangan bangsa yang memiliki peran strategis, ciri dan sifat khusus yang menjamin kelangsungan eksistensi bangsa dan negara pada masa depan. Agar setiap anak kelak mampu memikul tanggung jawab tersebut, maka ia perlu mendapat kesempatan yang seluas-luasnya untuk tumbuh dan berkembang secara optimal, baik fisik, mental maupun sosial, dan berakhlak mulia. Oleh karena itu, perlu dilakukan upaya perlindungan untuk mewujudkan kesejahteraan anak dengan memberikan jaminan terhadap pemenuhan hak -haknya serta adanya perlakuan tanpa diskriminasi. Penelitian ini dilakukan dengan tujuan mendeskripsikan bagaimana perlindungan hukum terhadap anak sebagai korban perdagangan orang berdasarkan Undang-undang Nomor 35 Tahun 2014 Tentang Perlindungan Anak serta bagaimana sanksi terhadap pelaku tindak pidana perdagangan anak. Metode penelitian yang digunakan dalam penelitian ini adalah penelitian hukum normatif. Hasil penelitian ini menunjukkan bahwa perlindungan hukum terhadap anak sebagai korban perdagangan orang berdasarkan Undang-undang Nomor 35 Tahun 2014 Tentang Perlindungan Anak meliputi perlindungan akan harkat dan martabat, serta pengakuan terhadap hak-hak asasi manusia yang dimiliki oleh anak berdasarkan ketentuan hukum dari kesewenangan. Selain itu, sanksi terhadap pelaku tindak pidana perdagangan anak telah diatur di dalam Undang-undang Nomor 21 Tahun 2007 Tentang Pemberantasan Tindak Pidana Perdagangan Orang.
\end{abstract}

Kata Kunci: Anak; Perdagangan orang; Tindak pidana

\begin{abstract}
Children are a mandate and a gift from God Almighty. Dignity as a human being is also inherent in them. Children are the potential successor and young generation who carry forward the ideals of the nation's struggle. They have a strategic role and special characteristics that ensure the continuity of the nation and state in the future. In order for each child to be able to bear this responsibility in the future, she/he needs to have the widest possible opportunity to grow and develop optimally, physically, mentally, socially, and nobly. Therefore, it is necessary to make efforts to protect the welfare of children by providing guarantees for the fulfillment of their rights as well as treatment without discrimination. This research was conducted with the aim of describing how the legal protection of children as victims of trafficking in persons based on Law Number 35 of 2014 concerning Child Protection and how the sanctions against the perpetrators of child trafficking. The research method used in this research was normative legal research. The results of this study indicated that legal protection for children as victims of trafficking in persons based on Law Number 35 of 2014 concerning Child Protection includes the protection of dignity, as well as recognition of human rights possessed by children based on legal provisions of abuse. In addition, the sanctions against the perpetrators of child trafficking are regulated in Law Number 21 of 2007 concerning the Eradication of the Crime of Trafficking in Persons.
\end{abstract}

Keywords: Children; Trafficking in Person; Crime

\section{PENDAHULUAN}

Setiap orang sebagai makhluk Tuhan Yang Maha Esa memiliki hak-hak asasi sesuai dengan kemuliaan harkat dan martabatnya yang dilindungi oleh undang-undang berdasarkan Pancasila dan Undang-undang Dasar Negara Republik Indonesia Tahun 1945. Dengan kata lain, seseorang berhak dan wajib diperlakukan sebagai manusia yang memiliki derajat yang sama dengan yang lain.

Secara universal anak mempunyai hak asasi manusia yang dilindungi hukum bahkan berlaku sejak dalam kandungan (Fahlevi, 2015; Fitriani, 2016; Sudrajat, 2011). Oleh karena itu, anak juga berhak mendapat perlindungan hukum atas segala kegiatan yang mengarah pada pertumbuhan 
maupun perkembangan di masa mendatang. Agar semua berjalan sesuai dengan hak universal anak, diperlukan kebersamaan semua pihak sehingga tahun 2015 program menciptakan anak sehat bisa menjadi kenyataan, apalagi Undang-undang No. 23 Tahun 2002 Tentang Perlindungan Anak menegaskan bahwa negara, pemerintah, masyarakat, keluarga dan orang tua mempunyai tanggung jawab pemeliharaan dan perlindungan anak.

Anak adalah amanah dan karunia Tuhan Yang Maha Esa yang dalam dirinya juga melekat harkat dan martabat sebagai manusia seutuhnya (UU Nomor 23 Tahun 2002 tentang Perlindungan Anak). Anak adalah tunas, potensi, dan generasi muda penerus cita-cita perjuangan bangsa yang memiliki peran strategis dan mempunyai ciri dan sifat khusus yang menjamin kelangsungan eksistensi bangsa dan negara pada masa depan. Agar setiap anak kelak mampu memikul tanggung jawab tersebut, maka ia perlu mendapat kesempatan yang seluas -luasnya untuk tumbuh dan berkembang secara optimal, baik fisik, mental maupun sosial, dan berakhlak mulia. Jadi, perlu dilakukan upaya perlindungan untuk mewujudkan kesejahteraan anak dengan memberikan jaminan terhadap pemenuhan hak-haknya serta adanya perlakuan tanpa diskriminasi.

Undang-undang Nomor 23 Tahun 2002 tentang Perlindungan Anak (selanjutnya disebut dengan Undang-undang Perlindungan Anak) merupakan peraturan khusus yang mengatur mengenai masalah anak.Tujuan dari perlindungan anak sendiri disebutkan dalam Pasal 3 UU Perlindungan Anak "Perlindungan anak bertujuan untuk menjamin terpenuhinya hak-hak anak agar dapat hidup, tumbuh, berkembang, dan berpartisipasi secara optimal sesuai dengan harkat dan martabat kemanusiaan, serta mendapat perlindungan dari kekerasan dan diskriminasi, demi terwujudnya anak Indonesia yang berkualitas, berakhlak mulia, dan sejahtera".

Pengingkaran terhadap kemuliaan hak asasi seorang anak akan terjadi apabila ada seseorang yang tidak lagi memandang seorang anak sebagai sebuah subjek yang sama dengan dirinya, tetapi lebih pada pandangan sebagai sebuah objek yang bisa diperjualbelikan demi keuntungan pribadi. Bisnis perdagangan orang saat ini banyak menjerat anak. Bisnis seperti ini merupakan tindakan yang bertentangan dengan harkat dan martabat manusia dan melanggar hak asasi manusia. Perdagangan anak sendiri sebenarnya telah meluas dalam bentuk jaringan kejahatan yang terorganisasi dan tidak terorganisasi, baik bersifat antarnegara maupun dalam negeri sehingga menjadi ancaman terhadap masyarakat, bangsa, dan negara, serta terhadap norma -norma kehidupan yang dilandasi penghormatan terhadap hak asasi manusia (Daud \& Sopoyono, 2019; Mustafid, 2019; Suhardin, 2008).

Anak-anak dan perempuan merupakan pihak yang rentan menjadi korban trafficking dan eksploitasi. Mereka yang menjadi korban sebagian besar berasal dari kelompok masyarakat yang rentan. Perlindungan terhadap hak anak merupakan hak asasi manusia yang dijamin oleh konsitusi negara Undang- undang Dasar Republik Indonesia yaitu pada Pasal 28b. Dalam hal ini anak perlu mendapat kesempatan yang seluas-luasnya untuk tumbuh dan berkembang secara optimal, baik fisik, mental maupun sosial.

Dalam Undang-undang No. 35 Tahun 2014 tentang Perlindungan Anak Pasal 59 menyebutkan bahwa Pemerintah dan Lembaga Negara berkewajiban dan bertanggung jawab untuk memberikan perlindungan khusus kepada anak dalam situasi darurat, anak yang berhadapan dengan hukum, anakanak dari kelompok minoritas dan terisolasi, anak yang tereksplotasi secara ekonomi dan/ atau seksual, serta anak yang diperdagangkan.

Perdagangan anak adalah rekrutmen, transportasi, pemindahan, penyembunyian atau penerimaan seorang anak untuk tujuan eksploitasi di dalam atau antar negara yang tetapi tidak terbatas pada prostitusi anak, pornografi anak, dan bentuk lain dari eksploitasi seksual pekerja anak, kerja paksa atau pelayanan, perbudakan atau praktek lain yang menyerupai perbudakan, penghambaan, pemindahan atau perjualan organ tubuh, penggunakan aktivitas terlarang/tidak sah dan keikutsertaan dalam konflik bersenjata.

Modus perdagangan anak semakin tahun semakin maju, cotohnya saat ini banyak terjadi tindak pidana perdagangan manusia secara online untuk menarik pengguna media sosial. kemudian ada juga modus pernikahan yang kemudian dieksploitasi baik seksual ataupun eksploitasi ekonomi dan banyak modus lainnya lagi. Keterdesakan masalah ekonomi merupakan penyebab utama banyaknya perempuan dan anak terjerumus dalam lingkaran perdagangan orang. Masalah ekonomi menjadikan manusia mencari jalan keluar yang mudah dan cepat untuk memenuhi setiap kebutuhannya. Hal ini 
terjadi karena ketersediaan lapangan pekerjaan tidak lagi sesuai dengan laju pertumbuhan penduduk dan pertumbuhan perekonomian (Hatta, 2012).

Berdasarkan uraian latar belakang tersebut di atas, maka penelitian ini dirumuskan dengan tujuan mendeskripsikan bagaimana perlindungan hukum terhadap anak sebagai korban perdagangan orang berdasarkan Undang-undang Nomor 35 Tahun 2014 Tentang Perlindungan Anak dan bagaimanan sanksi terhadap pelaku tindak pidana perdagangan anak.

\section{METODE PENELITIAN}

Penelitian ini merupakan penelitian hukum normatif. Penelitian hukum ini merupakan suatu tipe penelitian yang mengkaji suatu peraturan perundang-undangan yang berlaku dan berkompeten untuk digunakan sebagai dasar dalam memecahkan sebuah permasalahan. Pendekatan yang digunakan dalam penelitian ini adalah pendekatan perundang-undangan (Statute Approach) dan pendekatan konseptual (Conceptual Approach). Sumber bahan hukum yang digunakan dalam penelitian ini dibagi menjadi bahan hukum primer dan bahan hukum sekunder. Bahan hukum primer berupa peraturan Perundang-Undangan yakni Undang-undang Dasar Negara Republik Indonesia 1945, Undang-undang Nomor 35 Tahun 2014 tentang Perlindungan Anak, Undang-undang Nomor 21 Tahun 2007 tentang Pemberantasan Tindak Pidana Perdagangan Orang dan Kitab Undang- Undang Hukum Pidana (KUHP). Bahan hukum sekunder bersumber dari kepustakaan yaitu berupa literatur-literatur, dokumen-dokumen yang berkaitan dengan perlindungan anak yang menjadi korban perdagangan orang, artikel-artikel yang ada di internet (artikel hukum) serta pandangan ahli hukum.

Pengumpulan bahan hukum mulai dari primer dan bahan hukum sekunder yang dilakukan dengan system kartu (card system), dimana pengumpulan bahan ini dilakukan dengan cara meneliti peraturan perundang-undangan dan berbagai literatur yang masih berlaku dan berkaitan dengan penelitian ini, kemudian dicatat dalam note (buku tulis) dengan mencantumkan nama pengarang, judul buku, nama penerbit, dan tahun terbit. Selain itu, beberapa studi dokumen digunakan dengan mencatat keseluruhan bahan hukum yang relevan dengan permasalahan.

Teknik analisis terhadap bahan-bahan hukum yang terkumpul dilakukan dengan langkahlangkah: deskripsi, interpretasi dan argumentasi. Teknik deskripsi tidak dapat dihindari penggunaannya karena sebagai dasar untuk menganalisis semua bahan-bahan hukum yang berhubungan dengan permasalahan yang akan dibahas. Diskripsi berarti menguraikan kondisi atau posisi hukum apa adanya mengenai bagaimana peraturan perundang-undangan tersebut berlaku dalam hal ini.

\section{HASIL DAN PEMBAHASAN}

\section{Perlindungan Hukum terhadap Anak sebagai Korban Perdagangan Orang Berdasarkan Undang-Undang Nomor 35 Tahun 2014 Tentang Perlindungan Anak}

Di Indonesia sendiri terdapat beberapa pengertian tentang anak menurut peraturan perundangundangan dan juga menurut para pakar ahli. Namun di antara beberapa pengertian tidak ada kesamaan mengenai pengertian anak tersebut karena dilatarbelakangi dari maksud dan tujuan masing-masing undang-undang maupun para ahli. Pengertian anak menurut peraturan perundangundangan dapat dilihat sebagai berikut.

a) Anak Menurut UU No. 23 Tahun 2002 tentang Perlindungan Anak.Pengertian anak berdasarkan Pasal 1 ayat (1) UU No 23 Tahun 2002 tentang Perlindungan Anak adalah seseorang yang belum berusia 18 (delapan belas) tahun, termasuk anak yang masih dalam kandungan (Undang-undang No 23 tahun 2002: 4).

b) Anak menurut Kitab Undang-undang Hukum perdata dalam Pasal 330 Kitab Undang-undang Hukum Perdata, mengatakan orang belum dewasa adalah mereka yang belum mencapai umur 21 tahun dan belum menikah. Jadi anak adalah setiap orang yang belum berusia 21 tahun dan belum menikah. Seandainya seorang anak telah menikah sebelum umur 21 tahun kemudian bercerai atau ditinggal mati oleh suaminya sebelum genap umur 21 tahun, maka ia tetap dianggap sebagai orang yang telah dewasa bukan anak-anak (Subekti \& Tjitrosudibio, 2008).

c) Menurut Kitab Undang-undang Hukum Pidana Anak dalam Pasal 45 KUHPidana adalah anak yang umurnya belum mencapai 16 (enam belas) tahun. 
d) Menurut Undang-undang No 4 Tahun 1979 tentang Kesejahteraan Anak Yang disebut anak adalah seseorang yang belum mencapai umur 21 (dua puluh satu) tahun dan belum pernah kawin (Pasal 1 butir 2 UU Kesejahteraan Anak Tahun 1997.

e) Menurut Undang-Undang Nomor 11 Tahun 2012 Tentang Sistem Peradilan Pidana Anak Dijelaskan dalam Pasal 1 Ayat 3 UU Kesejahteraan Anak 1997 Anak adalah anak yang telah berumur 12 (dua belas) tahun, tetapi belum berumur 18 (delapan belas) tahun yang diduga melakukan tindak pidana.

f) Menurut Pasal 1 butir 5 Undang-undang Nomor 39 Tahun 1999 tentang Hak Asasi Manusia, anak adalah setiap manusia yang berusia di bawah 18 (delapan belas) tahun dan belummenikah, termasuk anak yang masih dalam kandungan apabila hal tersebut demi kepentingannya.

Dalam lingkup Undang-undang tentang Hak Asasi Manusia serta Undang- undang tentang Perlindungan Anak sendiri ditetapkan bahwa anak adalah seseorang yang belum mencapai usia 18 tahun termasuk anak yang masih dalam kandungan dan belum pernah menikah.

Trafficking perempuan dan anak adalah segala tindakan pelaku trafficking yang mengandung salah satu atau lebih tindakan perekrutan, pengangkutan antar daerah dan antar negara, pemindahtanganan, pemberangkatan, penerimaan dan penampungan sementara atau di tempat tujuan, perempuan dan anak. Hal ini dilakukan dengan ancaman, penggunaan kekerasan verbal dan fisik, penculikan, penipuan, tipu muslihat, memanfaatkan posisi kerentanan (misalnya ketika seseorang tidak memiliki pilihan lain, terisolasi, ketergantungan obat, jebakan hutang dan lain-lain), memberikan atau menerima pembayaran atau keuntungan, di mana perempuan dan anak digunakan untuk tujuan pelacuran dan eksploitasi seksual (termasuk phaedopilia), buruh migran legal maupun ilegal, adopsi anak, pekerjaan jermal, pengantin pesanan, pembantu rumah tangga, mengemis, industri pornografi, pengedaran obat terlarang, dan penjualan organ tubuh, serta bentuk-bentuk eksploitasi lainnya.

Definisi perdagangan orang yang diberikan oleh Pemerintah Republik Indonesia melalui Undang-undang No. 21 Tahun 2007 tentang Pemberantasan Tindak Pidana Perdagangan Orang (Selanjutnya disingkat UUPTPP0) yang rumusannya: Perdagangan orang adalah tindakan perekrutan, pengangkutan, penampungan pengiriman, pemindahan, atau penerimaan seseorang dengan ancaman kekerasan, penggunaan kekerasan, penculikan, penyekapan, pemalsuan, penipuan, penyalahgunaan kekuasaan atau posisi rentan, penjeratan utang atau memberi bayaran atau manfaat, sehingga memperoleh persetujuan dari orang yang memegang kendali atas orang lain tersebut, baik yang dilakukan di dalam negara maupun antar negara, untuk tujuan eksploitasi atau mengakibatkan orang tereksploitasi. Definisi yang terdapat di dalam Undang-undang No. 21 Tahun 2007 sudah merupakan perluasan dari definisi-definisi yang telah ada tentang Perdagangan Orang.

Kata Eksploitasi dalam Pasal 1 UU trafficking dipisahkan dengan eksploitasi seksual yang kemudian dijelaskan bahwa eksploitasi adalah tindakan dengan atau tanpa persetujuan korban yang meliputi tetapi tidak terbatas pada pelacuran, kerja atau pelayanan paksa, perbudakan atau praktik serupa perbudakan, penindasan, pemerasan, pemanfaatan fisik, seksual, organ reproduksi, atau secara melawan hukum memindahkan atau mentransplantasi organ dan/atau jaringan tubuh atau memanfaatkan tenaga atau kemampuan seseorang oleh pihak lain untuk mendapatkan keuntungan baik materiil maupun immateriil.

Dari definisi-definisi tersebut di atas dapat disimpulkan bahwa unsur-unsur Perdagangan Manusia adalah sebagai berikut:

1. Adanya tindakan atau perbuatan, seperti perekrutan, transportasi, pemindahan, penempatan dan penerimaan orang.

2. Dilakukan dengan cara, menggunakan ancaman atau penggunaan kekerasan atau bentuk-bentuk paksaan lain, penculikan, tipu daya, penyalahgunaan kekuasaan, pemberian atau penerimaan pembayaran/keuntungan untuk memperoleh persetujuan.

3. Ada tujuan dan maksud yaitu untuk tujuan ekspolitasi dengan maksud mendapatkan keuntungan dari orang tersebut.

Perlindungan hukum adalah berbagai upaya hukum yang harus diberikan oleh aparat penegak hukum untuk memberikan rasa aman, baik secara pikiran maupun fisik dari gangguan dan berbagai ancaman dari pihak manapun (Rahardjo, 1997). Perlindungan hukum adalah perlindungan akan harkat dan martabat, serta pengakuan terhadap hak-hak asasi manusia yang dimiliki oleh subyek hukum berdasarkan ketentuan hukum dari kesewenangan atau sebagai kumpulan peraturan atau kaidah yang 
akan dapat melindungi suatu hal dari hal lainnya. Berkaitan dengan konsumen, berarti hukum memberikan perlindungan terhadap hak-hak pelanggan dari sesuatu yang mengakibatkan tidak terpenuhinya hak-hak tersebut (Hadjon, 1987: 25).

Menurut Setiono, perlindungan hukum adalah tindakan atau upaya untuk melindungi masyarakat dari perbuatan sewenang-wenang oleh penguasa yang tidak sesuai dengan aturan hukum, untuk mewujudkan ketertiban dan ketentraman sehingga memungkinkan manusia untuk menikmati martabatnya sebagai manusia (Setiono, 2004: 3).

Menurut Muchsin, perlindungan hukum merupakan suatu hal yang melindungi subyek-subyek hukum melalui peraturan perundang-undangan yang berlaku dan dipaksakan pelaksanaannya dengan suatu sanksi. Perlindungan hukum dapat dibedakan menjadi dua, yaitu: Perlindungan Hukum Preventif, perlindungan yang diberikan oleh pemerintah dengan tujuan untuk mencegah sebelum terjadinya pelanggaran. Hal ini terdapat dalam peraturan perundang-undangan dengan maksud untuk mencegah suatu pelanggaran serta memberikan rambu-rambu atau batasan-batasan dalam melakukan sutu kewajiban. Dan, Perlindungan Hukum Represif, perlindungan akhir berupa sanksi seperti denda, penjara, dan hukuman tambahan yang diberikan apabila sudah terjadi sengketa atau telah dilakukan suatu pelanggaran (Setiono, 2004: 20).

\section{Sanksi Hukum terhadap Pihak yang Melakukan Tindak Pidana Perdagangan Orang}

Undang-undang Nomor 21 Tahun 2007 tentang Pemberantasan Tindak Pidana Perdagangan Orang yang merupakan upaya pemerintah dalam memberikan perlindungan hukum, baik secara langsung maupun tidak langsung terhadap calon korban dan/atau korban, juga berhubung dengan Undangundang Nomor 13 Tahun 2006 tentang Perlindungan terhadap Saksi dan Korban. Oleh karena itu, untuk melakukan pencegahan dan penegakan hukum yang tujuannya untuk melindungi HAM dapat dilakukan dengan diawali dari mengidentifikasi penyebab terjadinya TPPO. Undang-Undang Nomor 13 Tahun 2006 merupakan suatu langkah positif dalam upaya perlindungan saksi dan korban, yang selama ini masih diatur secara sektoral. Undang-undang No. 21 Tahun 2007 ini merupakan suatu kemajuan terhadap perlindungan korban sesuai dengan amanat pembukaan UUD 1945 yaitu melindungi segenap bangsa Indonesia dan seluruh tumpah darah Indonesia (Setiono, 2004: 292).

Berdasarkan Undang-Undang Nomor 21 Tahun 2007 tentang Pemberntasan Tindak Pidana Perdagangan Orang: Pasal 2 ayat 1 (satu) Setiap orang yang melakukan perekrutan, pengangkutan, penampungan, pengiriman, pemindahan, atau penerimaan seseorang dengan ancaman kekerasan, penggunaan kekerasan, penculikan, penyekapan, pemalsuan, penipuan, penyalahgunaan kekuasaan atau posisi rentan, penjeratan utang atau memberi bayaran atau manfaat walaupun persetujuan dari orang yang memegang kendali atas orang lain untuk tujuan mengeksploitasi orang tersebut di wilayah negara Republik Indonesia, dipidana dengan pidana penjara paling singkat 3 (tiga) tahun dan paling lama 15 (lima belas) tahun dan pidana denda paling sedikit Rp120.000.000,00 (seratus dua puluh juta rupiah) dan paling banyak Rp600.000.000,00 (enam ratus juta rupiah).

\section{Pasal 3}

Setiap orang yang memasukkan orang ke wilayah negara Republik Indonesia dengan maksud untuk dieksploitasi di wilayah negara Republik Indonesia atau dieksploitasi di negara lain dipidana dengan pidana penjara paling singkat 3 (tiga) tahun dan paling lama 15 (lima belas) tahun dan pidana denda paling sedikit Rp120.000.000,00 (seratus dua puluh juta rupiah) dan paling banyak Rp600.000.000,00 (enam ratus juta rupiah).

\section{Pasal 4}

Setiap orang yang membawa warga negara Indonesia ke luar wilayah negara Republik Indonesia dengan maksud untuk dieksploitasi di luar wilayah negara Republik Indonesia dipidana dengan pidana penjara paling singkat 3 (tiga) tahun dan paling lama 15 (lima belas) tahun dan pidana denda paling sedikit Rp120.000.000,00 (seratus dua puluh juta rupiah) dan paling banyak Rp600.000.000,00 (enam ratus juta rupiah).

\section{Pasal 5}

Setiap orang yang melakukan pengangkatan anak dengan menjanjikan sesuatu atau memberikan sesuatu dengan maksud untuk dieksploitasi dipidana dengan pidana penjara paling singkat 3 (tiga) tahun dan paling lama 15 (lima belas) tahun dan pidana denda paling sedikit Rp120.000.000,00 (seratus dua puluh juta rupiah) dan paling banyak Rp. 600.000.000,00 (enam ratus juta rupiah). 
Pasal 6

Setiap orang yang melakukan pengiriman anak ke dalam atau ke luar negeri dengan cara apa pun yang mengakibatkan anak tersebut tereksploitasi dipidana dengan pidana penjara paling singkat 3 (tiga) tahun dan paling lama 15 (lima belas) tahun dan pidana denda paling sedikit Rp. 120.000.000,00 (seratus dua puluh juta rupiah) dan paling banyak Rp. 600.000.000,00 (enam ratus juta rupiah).

\section{SIMPULAN DAN SARAN}

\section{Simpulan}

Berdasarkan uraian sebelumnya, maka dapat dibuat beberapa simpulan. Pertama, perlindungan hukum adalah segala bentuk upaya pengayoman terhadap harkat dan martabat manusia serta pengakuan terhadap hak asasi manusia di bidang hukum. Prinsip perlindungan hukum bagi rakyat Indonesia bersumber pada Pancasila dan konsep Negara Hukum. Kedua sumber tersebut mengutamakan pengakuan serta penghormatan terhadap harkat dan martabat manusia. Dalam lingkup Undang-undang tentang Hak Asasi Manusia serta Undang-undang tentang Perlindungan Anak sendiri ditetapkan bahwa anak adalah seseorang yang belum mencapai usia 18 tahun, termasuk anak yang masih dalam kandungan, dan belum pernah menikah. Oleh sebab itu, anak seharusnya sangat terlindungi dari berbagai macam ancaman tindak pidana. Namun karena faktor ekonomi yang sulit, faktor ekologi, sosial budaya, dan ketidaksetaraan gender, serta minimnya pengetahuan terhadap perlindungan hukum membuat anak sering kali menjadi korban dari tindak pidana perdagangan orang. Kedua, sanksi terhadap Tindak Pidana Perdagangan Orang (Human Trafficking) diatur di dalam Undang-undang Nomor 21 Tahun 2007 tentang Pemberantasan Tindak Pidana Perdagangan Orang.

\section{Saran}

Dalam rangka mewujudkan sanksi pidana yang lebih relevan dan memiliki rasa keadilan bagi para korban, maka ada beberapa saran yang diberikan untuk penegakan hukum yang menyangkut perdagangan orang (Human Trafficking) di Indonesia, yaitu: pertama, perlu diadakan sedikit perubahan dan/atau pembaharuan terhadap Undang-undang Nomor 21 Tahun 2007 agar dapat lebih tegas mengatur sanksi dan denda serta lebih mendetail mengatur tentang perdagangan orang (Human Trafficking). Kedua, para aparat penegak hukum hendaknya mengacu dan berpedoman pada peraturan undang-undang sehingga tetap membela kepentingan umum atau masyarakat bukan golongan dan pribadi, serta meningkatkan upaya pencegahan untuk mencegah atau mengurangi terjadinya perdagangan orang (Human Trafficking) di antaranya meningkatkan kualitas pendidikan masyarakat, menyediakan lapangan pekerjaan yang luas, meningkatkan kesejahteraan masyarakat dan sosialisasi Undang-Undang serta kesadaran terhadap hukum.

\section{DAFTAR PUSTAKA}

Daud, B. S., \& Sopoyono, E. (2019). Penerapan Sanksi Pidana Terhadap Pelaku Perdagangan Manusia (Human Trafficking) Di Indonesia. Jurnal Pembangunan Hukum Indonesia, 1(3), 352365.

Fahlevi, R. (2015). Aspek Hukum Perlindungan Anak dalam Prespektif Hukum Nasional. Lex Jurnalica (Journal of Law), 12(3), 177-191.

Fitriani, R. (2016). Peranan Penyelenggara Perlindungan Anak dalam Melindungi dan Memenuhi Hak-Hak Anak. Jurnal Hukum : Samudra Keadilan, 11(2), 250-258.

Hadjon, P. M. (1987). Perlindungan Bagi Rakyat Indonesia. PT. Bina Ilmu.

Hatta, M. (2012). Tindak Pidana Perdagangan Orang dalam Teori dan Praktek. Liberty.

Mustafid, F. (2019). Perdagangan Orang dalam Perspektif HAM dan Filsafat Hukum Islam. AlAhkam: Jurnal Pemikiran Hukum Islam, 29(1), 85-108.

Rahardjo, S. (1997). Masalah Penegakan Hukum suatu Tinjauan Sosiologis. Sinar Baru.

Setiono. (2004). Rule of Law (Supremasi Hukum). Magister Ilmu Hukum Program Pascasarjana Universitas Sebelas Maret'.

Subekti, \& Tjitrosudibio. (2008). Kitab Undang-Undang Hukum Perdata. Pradnya Paramita.

Sudrajat, T. (2011). Perlindungan Hukum terhadap Hak Anak sebagai Hak Asasi Manusia dalam Perspektif Sistem Hukum Keluarga di Indonesia. Kanun: Jurnal Ilmu Hukum, 13(54), 111-132.

Suhardin, Y. (2008). Tinjauan Yuridis Mengenai Perdagangan Orang Dari Perspektif Hak Asasi Manusia. Mimbar Hukum - Fakultas Hukum Universitas Gadjah Mada, 20(3), 473-486. 
Kitab Undang-Undang Hukum Pidana

UU Nomor 23 Tahun 2002 tentang Perlindungan Anak

Undang-Undang Nomor 35 Tahun 2014 Tentang Perlindungan Anak

Undang-Undang Nomor 21 Tahun 2007 Tentang Pemberantasan Tindak Pidana Perdagangan Orang 